\title{
Pengaruh Implementasi Ekonomi Islam Dalam Membentuk Karakter Masyarakat Yang Islami
}

\section{The Effect of the Implementation of Islamic Economics in Shaping the Character of an Islamic Society}

\author{
Ach. Khiarul Waro Wardani \\ Institut Agama Islam Negeri Kediri \\ wardaniahmad25@gmail.com
}

\begin{abstract}
Islamic economy is in the middle of a developed society model which becomes a separate measure or barometer for practicing all transactions based on uluhiyah and insaniyha. As a representative of Islamic teachings that are able to provide benefits to all living things, Islamic economy is able to provide movement and influence on society in its economic practices. Islamic economics as part of the social sector tries to offer an economic action that is beneficial to all economic and social actors, which makes the existence of Islamic economics as a means of self-revolution from a capitalist concept that prioritizes personal gain towards Islamic behavior, namely prioritizing interests vertically (after all: God) and horizontal interests (humanity). The implementation of Islamic economics emerges from a set of basic Islamic laws, namely: Al-Quran and Hadith as the primary law and the ulama's ijtihad as the primary legal basis. Prophet Muhammad SAW, his companions and tabi'i, tabi'in and scholars in the past and present are a reflection of the level of building a good relationship with the progress of Islam as a civilized religion and as a barometer for shaping an Islamic character, namely upholding the values human value. In conditions like this, when mankind begins to neglect their own brothers because of their own enrichment (capitalism) so that they become uncivilized human beings, then here God's lovers give an example which then influences humans to become Islamic humans through the means of preaching, namely the concept. application or implementation of Islamic economics.
\end{abstract}

Keywords: economy, Islam, civil society, islamic character 


\begin{abstract}
Abstrak
Ekonomi islam berada di tengah model masyarakat yang majmuk menjadi sebuah ukuran atau barometer tersendiri untuk mempraktikkan segala transksi yang berdasarkan uluhiyah dan insaniyha. Sebagai representatif ajaran islam yang mampu memeberikan manfaat terhadap semua mahluk hidup, ekonomi islam yang mampu memberi pergerakan dan pengaruh terhadap masyarakat dalam praktik perekonomiannya. Ekonomi islam sebagai bagian dari sosial mencoba menawarkan suatu tindakan ekonomi yang bermanfaat terhadap seluruh pelaku ekonomi dan sosial, yang menjadikan existensi ekonomi islam sebagai alat revolusi diri dari faham kapitalis yang mengedepankan keuntungan pribadi menuju pada prilaku yang islami yaitu mengedapankan kepentingan secara vertikal (akherat: Tuhan) dan kepentingan horizontal (kemanusiaan). Implementasi ekonomi islam muncul dari sekumpulan dasar hukum islam, yaitu: Al-Quran dan Hadist sebagai hukum primer dan ijtihad para ulama' sebagai dasar hukum primernya. Nabi Muhammad SAW, sahabatnya dan tabi'i, tabi'in dan ulama di masa lampau dan masa kini menjadi cerminan dalam tingkat membangun hubungan yang baik terhadap kemajuan islam sebagaai agama yang beradab dan sebagai barometer untuk membentuk karakter yang islami, yakni menjunjung tinggi nilainilai kemanusiaan. Pada kondisi seperti ini, disaat umat manusia mulai lalai terhadap saudaranya sendiri karna untuk memperkaya sendiri (kapitalisme) sehingga menjadi manusia yang tidak beradab, maka disini para kekasih Allah memberi contoh yang kemudian memberi pengaruh terhadap manusia agar menjadi manusia yang islami melalui alat dakwah yaitu konsep penerapan atau implementasi ekonomi islam.
\end{abstract}

Kata kunci: Ekonomi, Islam, Masyarakat, Karakter Islami

\title{
Pendahuluan
}

Islam sebagai suatu agama yang memiliki kebenaran haqiqi tentu di dalam ajarannya memiliki peranan penting dalam membentuk karakter suatu masyarakat dalam menjalankan keberlangsungan hidup. Islam sebagai agama yang mengajarkan tauhid, 'ubudiah dan juga mu'amalah, munakahah, islam juga mengajarkan bagaimana manusia atau masyarkat menjadi insan kamil 
Ach. Khiarul Waro Wardani | Pengaruh Implementasi...

yang subtantif. Yang mana menjadikan segala bentuk aktifitas manusia tersebut masuk dalam katagori ibadah karna Allah Ta'ala semata. Yang demikian, sesuai dengan firman Allah:

"dan Aku (Allah) tidak menciptakan jin dan manusia melainkan supaya mereka beribadah padaku.” (Q.S. Adz Dzariat: 56).

Dalam ketentuan inilah islam hadir, dengan membawa konsep perekonomian yakni ekonomi islam. Yang bertujuan untuk menjadikan manusia memiliki karakter yang islami supaya sesuai dengan agamnya. Sehingga banyak orang yang berkeinginan untuk mempelajari islam secara komprehensif.

Ekonomi islam menjadi bagian terpenting dalam membentuk karakter masyarkat yang islami, hal ini dapat dilihat di masyarakat bahwa hampir $85 \%$ hubungan sosial masyarkat terbentuk melalui interaksi ekonomi.

Islam yang salah satu dari sekian banyak ajaran di dalamnya, islam juga mengajarkan bermuamalah dengan konsep islam tentunya. Yang memberikan kesempatan kepada masyarakat untuk menjadikan islam sebagai landasan dasar dalam menjalankan praktik perekonomian.

Dengan berlangsungnya perekonomian secara sistematis melalui ekonomi islam tentunya, akan menjadikan masyarakat memiliki stayle baru (stayle islam) dalam menjalankan sosial. Seperti contoh: takut akan riba maka akan lebih berhati-hati dalam mempraktikkan akad jual beli, kahawatir akan dosa Gharar maka akan menjadikan diri lebih berhati-hati dalam interaksi transaksi. Dengan kehati-hatian yang selalu diterapkan dalam kehidupan dengan takut kepada allah maka tidak menjadi hal yang mustahil untuk menjadi diri yang secara otomatis akan memiliki kepribadian yang islami pula. Maka, dengan tanpa disadari terbentuklah masyarakat yang islami. 
Keberadaan ekonomi islam yang implementasiannya terjadi ditengahtengah masyarakat harusnya bukanlah menjadi trand baru, mengingat islam dengan ajarannnya yang dibawa Nabi Muhammad 1400 Tahun lalu telah mengajarkan tentang perekonomian yang mengubah dari perekonomian yang bersifat jahiliyyah menuju pada sistem baru yang modrn dan saling menguntungkan. Akan tetapi kehadiran ekonomi dunia sekarang seolah-olah mengubah pendangan tersebut. Yaitu menjadikan materi sebagai orientasi dari kebahagian dan ketenangan. Hal ini tentunya berbeda dengan islam, islam dalam hal perekonomian mengacu pada nilai-nilai ilahiyah serta insaniyah sehingga perimplikasi pada pembangunan prilaku yang mulia. dan dalam ekonomi islam menjadikan dekat dengan allah dan manfaat terhadap sesama manusia adalah orientasi dari sebuah kebahagiaan dan kedamaian.

Maka, secara tidak langsung bahwa untuk membangun kemanusiaan dan tatanan pemerintahan yang beradap perlu adanya satu tatatanan perekonomian, dan disinilah islam menawarkan satu sistem dalam pembangunan tersebut, yakni sistem perekonomian islam. Yang mana didalamnya penuh dengan sistem nilai-nilai dan norma-norma keadilan yang kongkrit.

\section{Pembahasan}

\section{Pengaruh Implementasi Perekonomian Islam Pada Era Rasulullah}

Praktik atau kegiatan ekonomi, seperti yang telah banyak didifinisikan oleh para pakar, secara garis besar dapat diartikan sebagai kegiatan manusia individu atau kelompok dalam memproduksi, mengkonsumsi, dan mendistribusikan untuk memenuhi segala kebutuhan sebagai tuntutan kehidupan. Pernyataan yang demikian selaras dengan yang disampaikan oleh Fathurrahman Djalil, yaitu: kegiatan ekonomi merupakan kegiatan manusia dalam memproduksi, konsumsi, dan distribusi untuk memenuhi hidupnya. 
Ach. Khiarul Waro Wardani | Pengaruh Implementasi...

Dalam kontek perekonomian. Bentuk suatu sistem ekonomi juga sangat berpengaruh terhadap beberapa aspek sosial yang nantinya berdampak terhadap karakter dalam suatu masyarakat.

Dalam tinjauan psikologi, perekonomian juga menjadi pengaruh besar dalam perubahan manusia baik dalam sekala kecil ataupun dalam sekala besar. Maka di dalam ajaran islam juga memperhatikan hal perekonomian sebagai bentuk penyelesaian permasalahan manusia. Yakni dengan menghadirkan ekonomi islam, sebagai alat untuk memenuhi kebutuhan dan sekaligus membentuk diri atau masyarakat yang islami.Yang demikian dijelaskan oleh Allah dalam firmannya, yang artinya:

"carilah dari apa yang telah Allah anugrahkan kepadamu untuk kebahagiaan negeri akhirat, dan janganlah kamu lupa bagianmu di dunia" (Q.S 28:77).

Dalam ayat ini jelas terlihat ada dua konsep yang perlu diperhatikan. Pertama: menjadikan diri untuk selalu mencari bekal akhirat dengan memperbanyak ibadah, dekat dengan Allah. dan yang kedua: menjadikan diri untuk tidak lupa untuk memperoleh harta benda dunia.

Kesinambungan dalam ayat tersebut adalah sebuah kepastian. mengingat sudah menjadi sifat sebagian manusia akan mudah terganggu ibadahnya jika dibenturkan dengan tekanan-tekanan ekonomi. Maka hadirlah ekonomi islam untuk memanagement kasuistik yang demikian. Ekonomi islam mengarahkan tetap menjadi pribadi yang islami detengah-tengah tekanan ekonomi.

Dari dasar ayat di atas, Rosulullah mengajarkan kita bagaimana cara mengimplentasikan ekonomi islam yang tetap sejalur dengan kaidah-kaidah ajaran islam yang benar.

Al-Quran dan Hadist membicarakan permasalahan ekonomi karena ekonomi dirasa sangat penting untuk mengatasi persoalan bagi kehidupan 
manusia. Cita-cita ekonomi sangat jelas dalam kitab suci umat islam. Cita-cita itu dapat disebut sebagai suatu cita-cita tentang keadilan sosial.

Pada zaman rosulullah penerapan ekonomi islam sangat berpengaruh terhadap kondisi masyarakat pada zaman beliau. Sehingga tidak heran agama islam sangat diterima oleh masyarakat arab (jahiliyah) pada zaman itu. Terlepas dari sistem 'ubudiah, munkahah, muamalah sosial yang ditawarkan agama islam. Rosulullah juga menawarkan ekonomi islam dalam menjalankan sistem perekonomian baik perekonomian secara mikro ataupun makro.

Penerimaan masyarakat pada zaman Rosululloh terhadap ekonomi islam yang dibawa Rosulullah benar-benar tepat sasaran terhadap cita-cita masyarakat zaman itu, yaitu merasakan keadilan sosial yang bersifat merata. Sebagaimana contoh kecil, dimana sistem perekonomian pada zaman Rosulullah sangat bisa diterima bangsa arab kala itu, yaitu penerapan jizyah atau pajak yang dibebankan kaum non muslim terkhusus terhadap ahli kitab. Sebagai bentuk jaminan keamanan dan keselamatan jiwa, keluarga, harta benda, dan kebebasan dalam menjalankan ritual peribadatan. Dalam implementasi pajak terhadap non muslim bukan berarti pada zaman Rosulullah umat muslim tidak dikenakan beban pajak, ada beban pajak yang berlaku terhadap umat islam, yaitu bemberlakuan ushr yaitu kewajiban mengeluarkan sebagian dari hasil pertanian, buah-buahan ataupun peternakan.hal ini berarti bahwa aktifitas ekonomi dalam islam adalah aktifitas kolektif, bukan individual. Yang mana Rosulullah mengadopsi sistem ushr atau jenis pajak pada zaman jahiliyah. Ushr disini jika diimplementasikan pada zaman sekarang adalah bea impor atau jual yang dikenakan kepada semua pedagang, yang mana pembayarannya dilakukan satu kali dalm setahun.

Dari contoh di atas, bisa kita lihat, dimana kebijakan-kebijakan yang Rosulallah berlakukan pada zaman beliau terdapat sebuah indikasi bahwa 
Ach. Khiarul Waro Wardani | Pengaruh Implementasi...

kenabian Rosulullah benar-benar haq. Mengingat beliau seorang pemuda yang ummy tidak dapat membaca dan menulis bisa membuat sebuah kebijakan yang dirasa dapat membawa keadilan. Tidak mungkin kebijakan ini dari Nabi Muhammad melainkan ini adalah sebuah wahyu.

Kebenaran Rosulullah sebagai seorang Nabi dijelaskan oleh Allah dalam firmannya, yang artinya:

"Muhammad itu sekali-kali bukanlah bapak dari seorang laki-laki diantara kamu, tetapi Dia adalah Rosulullah dan penutup para nabi-nabi. Dan adalah Allah maha mengetahui segala sesuatu”. (Q.S Al-Ahzab: 40).

Dan, ditambah lagi dengan sifat-sifat beliau, salah satunya adalah sifat dengan gelar Al-Amin yang berarti dapat dipercaya. Dengan sifat ahklaq yang mulia inilah menjadi awal dimana Rosulullah memberikan pengaruh besar terhadang bangsa arab.

Mengingat pada masa perjuangan, Rosulullah adalah seorang pedagang atau pelaku perekonomian, maka modal awal beliau adalah memiliki trusted (dipercaya). Dengan demikian keuntungan-keuntungan dalam perekonomian dengan konsep yang beliau implementasikan inilah dapat memberikan dapak pengaruh besar terhadap tatanan masyarakat di zaman beliau. Sehingga secara personal Rosulullah dapat memberikan pengaruh besar terhadap bangsa arab.

Rosulullah mengajarkan bagaimana dalam mengolah perekonomian tidak selalu mengedepankan kepentingan duniawi ataupun materi seperti yang dipraktikkan oleh faham kapitalis dengan mencari keuntungan sebesarbesarnya tanpa memperhitungkan kerugian orang lain, akan tetapi dalam menjalankan praktik perekonomian manusia juga harus mengedepankan fokus ilahiyah dan insaniyah. Bagaimana dengan menjalankan perekonomian dapat berdampak terhadap peningkatan iman dan bermanfaat terhadap sesama manusia. Demikian yang diajarkan Rosulullah dalam penerapan ekonomi 
islam. Dan ini sangat perpengaruh terhadap objek dakwah rosulullah (bangsa jahiliyah).

Dan, strategi melalui pengajaran ekonomi islam juga merupakan misi dakwah beliau dalam mengenalkan islam. Terkhusus dalam mempengaruhi bangsa arab melalui implementasi perekonomian islam dengan ahlaq yang baik dan terpuji. Sebagaimana dijelaskan dalam hadist yang shohih Dari Abu Hurairah berkata:

"Rasulullah saw. bersabda: "Tiadalah aku diutus kecuali hanya untuk menyempurnakan akhlak”. (HR. Ahmad).

Sehingga, cara Rosulullah ini juga diadopsi oleh para Wali Songo yang menyebarkan islam di Indonesia. Dengan cara berdagang dan memberikan pengaruh kepercaan agama islam sekaligus memberikan contoh untuk menjadi orang yang benar- benar islami (ahlak terpuji).

Pada zaman Rosulullah pengaruh implementasi ekonomi islam tidak hanya berpengaruh terhadap bangsa arab secara psikologi bangsa arab waktu itu, akan tetapi mencakup seluruh tatanan kehidupan masyarakat, yaitu berupa 1). Ketauhidan, 2). 'adl (keadilan), 3). Nubuwwah (kenabian), 4). Khilafah (pemerintahan atau politik), dan 5). Ma'ad (hasil).

Pengaruh-pengaruh ekonomi islam yang diterapkan Rosulullah ini dibuktikan dengan adanya beberapa konsep ekonomi syariah dalam islam yang dilakukan oleh para shohabat (khulafak rosyidun), tabi'in, dan pemimpinpemimpin islam yang lain hingga pemimpin-pemimpin islam kontemporer hingga saat ini.

Pengaruh ini tetap digunakan mengingat pengaruh implementasi ekonomi islam yang dibawa Rosulullah terbukti benar-benar dapat merubah tatanan kehidupan masyarakat pada zamn beliau. 
Ach. Khiarul Waro Wardani | Pengaruh Implementasi...

\section{Prinsip Dasar Perekonomian Islam}

Diutusnya Nabi Muhammad SAW sebagai pembawa risalah memberi angin segar terhadap pembaharuan prilaku pebisnis bangsa arab pada zaman tersebut, bembaharuan ini disebabkan negative culture dalam menjalankan sistem perekonomian. Prinsip mencari keuntungan dengan cara penerapan riba dijadikan alat oleh lintah darat dalam meraup keuntungan dari masyarakat. Dampak dari praktik perekonomian yang dilakukan bangsa jahiliyah tersebut tentunya berdampak negatif terhadap masyarkat, yaitu terjadinya ketimpangan di tengah-tengah masyarakat dengan kondisi yang kaya semakin kaya dan yang miskin tentunya akan menjadi semakin miskin. Yang kemudian berimplikasi terhadap kesenjangan sosial dengan status adanya strata sosial dan munculnya kasta yang nantinya ada kaum yang termaginalkan.

Pada zaman Rosulullah perekonomian dipraktikkan dengan cara yang relatif sederhana, akan tetapi kesederhanaan tersebut mampu mengantarkan terhadap prinsip-prinsip dasar dalam menjalankan perekonomian, yaitu implementasi terhadap komitmen yang tinggi terhadap norma-norma dan perhatian yang sangat besar terhadap keadilan sosial dn kesejahteraan yang merata.

Adapun prinsip-prinsip dasar ekonomi islam adalah sebagai berikut:

a. Prinsip tauhid

Prinsip tauhid dalam perekonomian memiliki esensial yang tinggi, mengingat prinsip ini mengajarkan tentang bahwasannya manusia harus menyadari bahwa segala sesuatu yang ada di langit dan di bumi adalah milik Allah sang pencipta alam semata, sebagaimana firman-NYA:

"Mereka (orang-orang kafir) berkata: "Allah mempunyai anak". Maha Suci Allah, bahkan apa yang ada di langit dan di bumi adalah kepunyaan Allah; semua tunduk kepada-Nya." (Q.S Al-Baqoroh: 116) 
"Tiadakah kamu mengetahui bahwa kerajaan langit dan bumi adalah kepunyaan Allah? Dan tiada bagimu selain Allah seorang pelindung maupun seorang penolong” (Q.S Al-Baqoroh: 107)

Pada ayat ini menyadarkan terhadap pelaku ekonomi, bahwa dalam menjalankan perekonomian haruslah menyeimbangkan antar hubungan horizontal (manusia) dan hubungan vertikal (Tuhan: Allah). dalam hubungannya manusia harus benar-benar sadar bahwa fasilitas yang allah berikan harus dikelola dengan sebenar-benarnya dengan mengedepankan keadilan sosial yang didasari dengan Al-Quran. sedangkan peran islam, menjadikan ekonomi sebagai alat pendekatan kepada Allah dengan cara menjadikan ekonomi sebagai fasilitas untuk meningkatkan beribadah kepadaNYA.

b. Prinsip 'adl al ijtima'iyah (keadilan)

Pada dasarnya prinsip keadilan merupakan suatu prinsip yang ada pada seluruh aspek kehidupan, tak terkecuali terhadap aspek ekonomi. Sebagaimana yang di sampaikan Sjaechul Hadi Poernomo sebagaimana dikutip oleh Abd. Shomad, tentang salah satu prinsip ekonomi adalah prinsip keadilan. Prinsip keadilan, mencakup seluruh aspek kehidupan, aspek ini merupakan aspek yang terpenting.

Berkenaan prinsip keadilan, Allah telah menyampaikan dalam firmannya yang artinya:

"sesungguhnya Allah menyuruh kamu berlaku adil dan berbuat kebajikan, memberi kepada kaum kerabat, dan Allah melarang dari perbuatan keji, kemungkaran dan permusuhan. Dia memberi pengajaran kepadamu agar kamu dapat mengambil pelajaran." (Q.S An-Nahl: 90)

Pada ayat ini secara eksplisit menjelaskan tentang keadilan, dimana keadilan merupakan kewajiban untuk diterapkan mengingat keadilan bagian dari perintah Allah. dan berikutnya Allah melarang kita untuk berbuat keji dan 
Ach. Khiarul Waro Wardani | Pengaruh Implementasi...

kemungkaran. Artinya jika manusia dalam menjalankan perekonomian khususnya, tidak mampu berbuat adil tentu akan berdampak pada permusuhan. Dan itu merupakan perbuatan yang keji dan mungkar.

c. Prinsip mas'uliyah (accuntability: tanggung jawab)

Prinsip mas'uliyah atau tanggung jawab telah Allah jelaskan dalam AlQuran yang artinya:

"dan tidaklah seseoarang berbuat dosa melainkan kemadhorotannya kembali kepada dirinya sendiri, dan seseorang yang berdosa tidak memikul dosa orang lain".

Dalam ayat yang lain, Allah menegaskan, yang artinya

"tiap-tiap diri bertanggung jawab atas apa yang telah diperbuatny" (Q.S AlMudatstsir: 38).

Pada ayat di atas secara jelas jika pertanggung jawaban hanya bersifat individu, akan tetapi pada ayat yang lain Allah katakan pula dalam firmanNYA, yang artinya:

"kami menuliskan apa-apa yang mereka kerjakan dan bekas- bekas yang mereka tinggalkan" (Q.S Yasiin: 12).

Dan, di jelaskan pula dalam dalam ayat yang lain, firman Allah, yang artinya:

"(ucapan mereka) menyebabkan mereka memikul dosa-dosanya dengan sepenuh-penuhnya pada hari kiamat dan sebagian dosa orang yang mereka sesatkan yang tidak mengetahui sedikitpun bahwa mereka disesatkan. ingatlah amat buruklah dosa yang mereka pikul itu” (Q.S An-Nahl: 25)

Dari ayat-ayat di atas menjelaskan prinsip dasar seseorang bertanggung jawab atas diri mereka sendiri. akan tetapi dalam aspek sosial ada masalah lagi 
yang cukup komplek, dimana seseorang salalu terlibat dengan orang lain. Begitu pula dalam kontek ekonomi.

Oleh sebab itu, dalam ekonomi islam memiliki prinsip mas'uliyah, dimana dalam menjalakan perekonomian seseorang harus dapat bertanggung jawab terhadap tuhannya (Allah), dirinya sendiri, dan juga orang lain.

d. Prinsip wasathiyah (keseimbangan)

Keseimbangan menjadi dasar prinsip dasar ekonomi islam berdasarkan atas asas gotong royong dan saling membutuhkan, yakni menciptakan suatu keseimbangan, sebagaimana saling membutuhkannya antara orang kaya dan orang fakir yakni membutuhkan pekerjaan dan butuh tenaga kerja, antara produsen dan konsumen, antara yang kuat dan yang lemah, dan masih banyak yang lainnya.

Prinsip wasathiyah (keseimbangan) ini, Allah firmankan dalam AlQuran yang artinya:

"dan dialah yang menjadikan kebun-kebun yang berjunjung dan tidak berjunjung, pohon kurma, tanam-tanaman yang bermacam-macam buahnya, zaitun dan delima yang serupa dan tidak sama, makanlah dari buahnya bila dia berubah, dan tunaikanlah haknya di hari memetik hasilnya dan janganlah kamu berlebih-lebihan, sesungguhnya Allah tidak menyukai orang-orang yang berlebih-lebihan" (Q.S Al-An'am: 141)

Pada ayat tersebut, menjadi dasar dalam prinsip perekonomian untuk benar-benar terwujud cita-cita bersama dalam membangun keseimbangan tatanan masyaarakat.

e. Prinsip tazkiyyah (penyucian)

Tazkiyyah memiliki arti penyucian. Dalam islam ada dua konsep penyucian, yaitu: 1). Penyucian jiwa dan 2). Penyucian harta benda. Pertama: penyucian jiwa, konsep ini Allah terangkan dalam Al-Quran yang artinya: 
Ach. Khiarul Waro Wardani | Pengaruh Implementasi...

"maka Allah mengilhamkan kepada jiwa itu jalan kefasikan dan ketaqwaan. Sesungguhnya beruntunglah orang orang yang menyuci-kan jiwa itu. dan sesungguhnya merugilah orang yang mengotorinya" (Q.S Asy-Syams: 9-10).

Ibnu Jarir Ath-Thobari menafsirkan ayat ini, bahwa orang-orang yang beruntung adalah mereka yang allah sucikan jiwanya dari kekufuran, kemaksiatan, serta memperbaikinya dengan amal sholeh. Kedua: penyucian harta benda, konsep kedua ini Allah terangkan dalam Al-Quran yang artinnya:

"ambillah zakat dari sebagian harta mereka, dengan zakat itu kamu membersihkan dan menyucikan mereka” (Q.S At-Taubah: 103).

Rosulullah menguatkan lagi dalam dalam ayat ini melalui hadist yang shohih "sesungguhnya Allah mewajibkan zakat sebagai penyucian harta" (H.R Bukhori).

Prinsip ini pulalah yang dijadikan dasar prinsip ekonomi islam. Selain dapat meningkatkan iman dengan ketakwaan, juga akan dapat menguatkan ikatan persaudaraan sebagai mahluk sosial.

f. Prinsip al-natayij walnajah (profit: hasil, untung dan kesuksesan)

Prinsip al-natayij walnajah merupakan inti dari perekonomian, baik itu ekonomi konfensional ataupun ekonomi syari'ah. Hal ini menjadi sangat penting bagi pelaku ekonomi karna hasil dan kesuksesan merupakan tujuan utama untuk menjalankan perekonomian.

Oeleh sebab itu, ajaran islam mengarahkan kepada manusia supaya mendapatkan hasil yang benar benar halalan toyyiban dan kesuksesan yang berkah.

Konsep hasil, untung ataupun laba dalam islam telah Allah firmankan dalam Al-Quran yang artinya: 
"dan janganlah sebagian kamu memakan harta sebahagian yang lain diantara kamu dengan jalan yang bathil dan janganlah kamu membawa urusan harta itu kepada hakim, supaya kamu dapat memakan sebahagian daripada harta benda orang lain itu dengan jalan berbuat dosa, padahal kamu mengetahuinya" (Q.S Al-Baqoroh: 188).

Pada yat ini, Rosulullah juga menegaskan dalam hadist-nya "Bahwasannya Rasululah saw. Berpapasan dengan seorang penjualmakanan, lalu beliau bertanya kepada orang itu, "bagaimana caramu menjual makanan ini?", dan orang itupun menerangkan apa yang ditanyakan Nabi itu. Kemudian Allah mewahyukan kepada beliau: "Masukkan tanganmu dalam makanan itu". Nabi lalu memasukkan tangan beliau, dan ternyata makanan yang ada di bagian bawahnya busuk. Maka beliau pun lalu berkata: "Bukanlah termasuk golongan kami, orang yang menipu kami". Juga riwayat dari Ibn 'Abbas, bahwasannya Rasulullah saw. bertemu dengan seorang penjual makanan di pasar Madinah yang amat menarik perhatian beliau. Lalu beliau memasukkan tangannya ke bahan makanan yang ada di bagian bawah, dan mengeluarkan sesuatu yang tidak sama dengan yang ada di permukaan. Maka beliau pun memarahi penjual makanan itu, dan kemudian berseru: Ayyuhā al-nās, tidak dibenarkan menipu dikalangan kaum Muslimin, dan barangsiapa yang menipu kami, ia tidak termasuk golongan kami. Jadi inti dari riwayat ini yaitu dilarangnya mengambil keuntungan dalam jual beli dengan jalan menipu"

Dari dalil diatas, sudah cukup menjelaskan bahwa dalam pengambilan laba, hasil atau keuntungan diperbolehkan selama tidak adanya tipu daya dan merugikan sesamanya. Prinsip ini diambil sebagai dasar prinsip dasar ekonomi islam dikarenakan pentingnya dalam menentukan keuntungan supaya tidak terjadi permusuhan diantara manusia dan konsep ini menjadi titik balik apakah orang tersebut katagori pelaku ekonomi yang sukses atupun tidak. 
Ach. Khiarul Waro Wardani | Pengaruh Implementasi...

Keuntungan adalah ketika bisa lebih dekat dengan allah dan terus terjalin hubungan antar manusia. Jika konsep ini dapat diterapkan tentu citacita untuk meraih kesuksesan akan terwujud.

Prinsip-prinsip dasar ekonomi islam disini merupakan jawaban sekaligus solusi dalam menjalankan perekonomian yang dapat memberi dampak perubahan terhadap individu ataupun masyarakat dalam mencapai sebuah cita-cita bersama. Sebagaimana perubahan-perubahan yang dibawa oleh Rosulullah dan para Shohabatnya. Dimana bumi yang dipijak bersama dapat dinikmati oleh sumua penghuninya, bukan hanya segelintir manusia.

\section{Peranan Ekonomi Islam Dalam Menbentuk Karakter Masyarakat Yang Islami}

Dalam islam peran sistem perekonomian sangatlah penting. Yang demikian terjadi, karena ekonomi merupakan salah satu faktor penting yang membawa pada kesejahteran umat. Maka, jika kesejahteraan yang memiliki tingkat yang berbeda-beda ini tidak dapat dimanagemen dengan baik maka, akan membentuk masyarkat yang tidak baik pula.

Secara psikologi hal ini sangat mungkin akan terjadi dikarenakan tanpa disadari strata sosial akan terbentuk dengan sendirinya. Oleh sebab itu, penting adanya filter dalam mengatasi hal tersebut, salah satunya adalah membentuk konsep ekonomi islam. Yang mana konsep ini berlandaskan terhadap AlQuran dan Hadist yang mengacu terhadap kepentingan bersama dalam mewujudkan masyarakat yang islami.

Kekuatan yang dimiliki oleh masyarakat terkumpul dalam suatu negara yang memiliki nilai-nilai regulasi yang bersifat mengikat, yaitu suatu negara yang mampu mengatasi kesejahteraan rakyatnya dan juga mampu merealisasikan kebijaksanaan dalam pentingnya perekonomian. 
Kebijaksanaaan yang dapat diterima oleh masyarakat ini nanti dapat menjadi suatu komitmen yang tinggi untuk menjalankan perekonomian. Seperti contoh pengharaman riba dalam ekonomi islam dikarenakan ada dampak negatif yang diterima. Kebijakan ini dapat diterima sekaligus menjadi komitmen masyaraakat islam khususnya untuk meninggalkan riba. Dan dengan berjalannya waktu akan menjadi sebuah budanya untuk meninggalkan praktik riba. Maka kebudayaan yang berlaku di masyarakat akan menjadi lebih islami, takut akan Sang pencipta dan akan dosa.

Pada dasarnya budaya merupakan cerminan dari masyarakat dalam segala pola kemasyarakatan baik cerminan dari pola pikir, prilaku, nilai dan norma yang dianut masyarakat tersebut. Apa yang dicerminkan maka itulah yang dipantulkan. Dari sudut pandang ini agama ikut berkontribusi dalam suatu kebudayaan masyarakat dalam setiap pola kehidupan, sehingga agama dapat mengakomodadif dengan budaya yang di anutnya.

Mengingat agama merupakan wahyu yang didalamnya terdapat dogma-dogma agama yang memiliki kebenaran absolut tentunya nilai atau kebudayaan dalam agama tidak dapat diselaras jajarkan dengan nilai dan budaya asli yang dianut oleh suatu masyarakat. Aakn tetapi agama (islam) dijadikan suatu sumber untuk memperbaiki, menguatkan atau merubah budaya yang ada, yang di anggap tidak sesuai dengan budaya syari'at agama. Bahkan agama harus menjadi sumber nilai bagi keberlangsungan nilai-nilai budaya itu sendiri.

Kebudayaan dalam suatu masyarakat juga menjadi pengaruh besar terhadap suatu peradaban suatu bangsa, jika suatu bangsa memiliki budaya jahiliyah tentunya kebudayaan tersebut akan menghantarkan kepada peradapan tertinggal atau bahkan akan menjadi peradaban yang tinggal sejarah. Sebagaimana yang disampaikan Koentjaraningrat, yaitu: beradaban 


\section{Ach. Khiarul Waro Wardani | Pengaruh Implementasi...}

juga sering dipakai untuk menyebut suatu kebudayaan yang memiliki sistem teknologi, seni bangunan, seni rupa, sistem kenegaraan dan ilmu pengetahuan yang maju. Artinya suatu budaya yang tidak memiliki hal-hal tersebut maka bisa dikatakan bangsa tersebut tidak memiliki keberadaban atau budayanya tidak menghantarkan terhadap suatu keberadaban.

Kebudayaan yang telah melahirkan karakter dalam suatu masyarakat telah ada sejak zaman Nabi Muhammad SAW dan bangsa pada zaman nabinabi terdahulu, dimana dengan budaya jahiliyah membentung bangsa dan masyarakat jahiliyah. Sebagai contoh dimana Rosulullah membentuk dan menempa karakter masyarakat madinah yang awalnya memiliki karakter manusia jahiliyah berubah menjadi msyarakat yang islami, yakni masyarakat yang hidup melalui ajaran dan tuntunan Al-Quran dan Hadist beliau. Secara historis Nabi Muhammad SAW telah membawa bangsa arap yang tidak hanya terbelakng dalam berniaga (ekonomi) akan tetapi juga terbelakang dalam segala hal. Sehingga bangsa arab kala itu tidak menjadi perhatian oleh bangsabangsa lainnya, hingga hadirnya Rosulullah di tengah-tengah mereka. Yang mana Rosulullah hadir dengan dua posisi yakni hadir sebagai utusan dari Allah (pemimpin kekuasaan sepiritual) kedua hadir sebagai kepala negara (pemimpin kekuasaan suatu bangsa).

Dalam kepemimpinannya Rosulullah, dengan wahyu yang Rosulullah bawa merubah karakter jahiliyah bangsa Arab ke arah karakter yang lebih cerdas. Salah satu yang dilakukan beliau adalah menegakkan perekonomian islam, yang mana esensi syari'ah islam yang di turunkan Allah adalah untuk mewujudkan kesejahteraan manusia secara keseluruhan. Hal ini dilakukan Rosulullah karna pada zaman jahiliyah sangat jauh dari kata sejahtera.

Sebagaimana dikemukakan oleh Abu Ishaq Al-Shatibi bahwa tujuan pokok disyariatkannya hukum islam adalah untuk kemaslahatan kemanusiaan 
baik di dunia maupun di akhirat. Lebih lanjut Abu Ishaq Al-Shatibimelaporkan hasil penelitian para ulamak terhadap ayat-ayat Al-Quran dan sunnah Rosulullah bahwa hukum-hukum yang disyariatkan Allah untuk mewujudkan kemaslahatan umat manusia, baik di dunia maupun di akherat kelak. Kemaslahatan yang akan diwujudkan itu menurut Abu Ishaq Al-Shatibi terbagi dalam tiga (3) tingkatan, yaitu: kebutuhan daruruyat, kebutuhan hajiyat, kebutuhan tahsiniyat.

Dalam pembentukan masyarakat yang keberadapan tentunya hal dan syarat utama adalah membentuk masyarakat yang sejahtera dengan berbagai kebudayaan yang ada. Konsep islam dalam memperhatikan suatu masyarakat yang sejahtera dalam suatu negara juga menekankan terhadap nilai budaya yang komprehensif, yang mana konsep islam dalam masyarakat mengatur prilaku seseoarang dalam kehidupan individu ataupun sosial, mengatur pengurusan dan mengelola harta benda, dan lain sebagianya. Tujuan dari petunjuk ini seperti yang tercantum di dalam Al-Quran dan Sunnah adalah untuk membentuk suatu masyarakat yang sehat didasarkan atas kesejahteraan umat manusia yang kekal.

Oleh sebab itu setiap manusia berhak untuk menjadikan diri sebagai pelaku ekonomi sebagai alat mencapai kesejahteraan. Dengan demikian, dengan kesejahteraan yang diperoleh secara otomatis akan merubah karakter diri seseoarang. Islam menawarkan ekonomi islam sebagai alat menuju kesejahteraan, dan dengan demikian jika kesejahteraan dapat diraih maka tanpa disadari seseoarang akan memerankan diri sebagai orang yang memiliki karakter yang islami, yakni semakin tinggi ketaqwaan kepada Allah, semakin dermawan terhadap sesama, dan juga perhatian terhadap kepentingan bersama.

Karakter yang islami tentunya harus benar-benar tertanam dalam diri manusia, terlebih terhadap orang yang bmenyakini bahwa tiada tuhan selain 
Ach. Khiarul Waro Wardani | Pengaruh Implementasi...

Allah dan Nabi Muhammad SAW adalah utusan Allah. yang mana karakter islami adalah suatu karakter yang memiliki kepedulian terhadap sesama, yakni terhadap kaum yang lemah (fisik atau financial) seperti yang terdapat dalam masyarakat secara umum, seperti buruh, petani, lansia, orang berkebutuhan khusus, du'afak, fakir miskin dan lain sebagianya.

Seabagi umat yang memeiliki karakter islami dengan ajaran islam yang dianutnya tentunya berkewajiban memberikan hak-haknya dengan cara yang baik dan dengan ukuran yang telah disyariatkan. Seperti yang telah dituangkan dalam Al-Quran dan Hadist-Hadist Rosulullah SAW.

Dengan demikian, ada beberapa peran yang harus diimplementasikan oleh orang yang berkarakter islami dalam kehidupan bermasyarakat sebagai pelaku ekonomi islam,

a. Menerapkan keadilan dalam takaran atau timbangan

Keadilan adalah sebuah konsep yang wajib diterapkan, hal ini untuk menghindari dari perbuatan curang dan memanipulasi harga. Yang mengakibatkan kerugian terhadap salah satu pihak. Allah berfirman, yang artinya:

"kecelakaan besarlah bagi orang-orang curang (yaitu) orang-orang yang apabila menerima takaran dari orang lain mereka minta dipenuhi, dan apabila mereka menakaratau menimbang untuk orang lain, mereka mengurangi" (Q.S Al-Muthoffifin: 1-3)

b. Larangan mempraktikkan riba

Sistem meriba merupakan suatu sistem yang banyak sekali digunakan oleh pelaku ekonomi terlebih oleh kaum kapitalis. Yang mana didalam sistem ini terdapat faktor-faktor yang nerugikan orang pihak lain dalam praktik ekonomi, seperti menggandakan pinjaman. 
Allah melarang praktik ini seperti yang difirmankan-NYA dalam Al-Quran, yang artinya:

"hai orang-orang yang beriman, janganlah kamu memakan riba denganberlipat ganda dan bertakwalah kamu kepada Allah supaya kamu mendapat keberuntungan. Dan peliharalah dirimu dari api neraka, yang disediakan untuk orang-orang jafir. Dan taatilah Allah dan Rosul supaya kamu dibri rahmat" (Q.S Ali "Imron: 130-132)

c. Jujur dalam praktir transaksi

Jujur dalam menjelaskan kondisi dan keadaan barang yang akan dijadikan barang jual beli. Jika kejujuran ini tidaklah ada tentunya akan berdampak buruk, buruk bagi penjual karna hilang kepercayaan dan buruk bagi pembeli karna mendapatkan kekecewaan. Dampak lain adalah akan berdampak buruk terhadap suatu communitas tertentu. Contoh: jika seseorang telah mendapatkan kekecewaan di suatu pasar tertentu maka orang tersebut akan beralih terhadap pasar yang lain. Maka communitas pasar yang awal akan mendapatkan citra yang huruk dikarenakan satu pedagang. Sehingga berdampak sepinya perptaran barang di pasar tersebut.

d. Pelarangan menimbun barang yang menjadi komoditas ekonomi.

Yaitu suatu praktik emnimbun barang komuditas hingga barang tersebut sepi dipasaran, setelah barang itu langka berikutnya barang tersebut dikeluarkan kembali dengan harga yang tinggi (tidak sesuai harga pasar pada umumnya). Praktik yang demikian, yakni menimbun harta komoditas (ikhtikar) tersebut akan memunculkan konsekuensi ketidak adanya keseimbangan suplay and demand, yang mana akan berimbas terhadap monopoli komoditas dan akan berdampak merugikan orang lain dibawah tekanan kebutuhan.

e. Menanamkan konsep sahl waraghib 
Ach. Khiarul Waro Wardani | Pengaruh Implementasi...

Yaitu suatu konsep dengan menanamkan konsep perekonomian yang mudah dilakukan dan dilakukan dengan cara rela sama rela (ridhi birridho). Adanya keterbukaan dalam penawaran barang dan harga, memudahkan dalam konsep transaksi, dan tidak terdapat paksaan. Jika tidak ada kerelaan dan kemudahan dalam bertransaksi maka subtansinya adalah adanya kerugian dalam melakukan proses jual beli baik dari pihak penjual ataupun dari pihak pembeli.

Peran-peran inilah yang nantinya harus di implemantasikan dalam praktek ekonomi sebagai bentuk wujud dari karakter masyarakat yang islami. Dan dalam bentuk muamalah sosial lainnya seperti terhadap keluarga, sanak saudara, tetangga dan communitas masyarakat lainnya. Makin dekat hubungan dengan tuhan sang pencipta (Allah SWT) dan semakin dekat pula hubungannya dengan sesama.

\section{Kesimpulan}

Islam sebagai agama yang memiliki aturan dalam menata tatanan kehidupan manusia memiliki peran yang sangat besar untuk menunjukkan jalan manusia kejalan yang benar dan membentuk pribadi dengan karakter yang islami. Yaitu suatu karakter yang memiliki nilai universal, suatu karakter manusia yang bisa diterima oleh semua golongan dengan adab dan pekerti luhur.

Nilai universal islam ini tidak hanya tertanam dalam nilai-nilai aqidah saja melainkan merambah terhadap nilai-nilai muamalah baik dalam sosial dan ekonomi. Yang mana nilai muamalah dalam islam yang disebut sebagai ekonomi islam ini memiliki subang sih yang besar dalam membentuk tatanan masyarakat yang memiliki karakter yang islami. 
Pengaruh yang ditanamkan oleh Rosulullah menjadi suatu pijakan atau sumber konkrit yang harus dijalankan untuk mencapai derajat manusia yang luhur baik di sisi Allah ataupun disisi manusia.

Ekonomi islam yang ditawarkan oleh manusia tentunya telah membawa perubahan tersediri terhadap manusia secara personal ataupun sebagai masyarakat sosial. Nilai-nilai dan norma-norma yang dipancarkan oleh sistem ajaran ekonomi islam merupan pancaran yang berdasar terhadap AlQuran dan Hadist yang mana sumber-sumber tersebut menjadi suatu pedoman manusia dalam menjalankan segala aktifitas kemanusian begitu pula dalam menjalankan sistem perekonomian.

Suatu prilaku yang dijalankan berdasarkan syariat islam yang dilhami oleh nilai-nilai uluhiyah dapat menjadi jembatan tersendiri bagi manusia dalam mencapai derajat insanul kamil, yang memiliki karakter prilaku manusia yang memiliki norma, yang keberadaannya dapat diterima oleh semua communitas manusia baik dalam besosial, beregulasi, dan dalam membentuk beradaban yang maju.

\section{Daftar Pustaka}

Al-Quran Dan Terjemah, Yayasan Penyelenggara Penterjemahan/Penafsir AlQuran, Departemen Agama RI, Jakarta

Al-shatibi, Abu ishaq, al-muwaffaqot, (bairut: dar al-ma'rifah, 1997)

Al-Suyuthi, Al-Hafizh Jalaluddin, Asbāb AL- Wurūd, alih Bahasa. O. Taufiqullah, Afif Mohammad , (Bandung: Pustaka, 1986)

Ascarya, Akad Dan Produk Akad Syariah (Praktek Dan Konsep Diberbagai Negara), (Bank Indonesia; tp,2006)

Ath-Thobari, Imam Ibnu Jarir, Jami' Al-Bayan An Ta'wil Ayi Al-Quran, (Bairut: Muassasah Ar Risalah,1420 H)

Depag. RI. Al Quran dan Terjemahnya , ( Semarang: Toha Putra 1998)

Dimyati, Ahmad, Islam Dan Koperasi,( Jakarta: KEMINFO, 1998) 
Ach. Khiarul Waro Wardani | Pengaruh Implementasi...

Djalil, Fathurrahman, Hukum Ekonomi Islam (Sejarah, Teori Dan Konsep), (Jakarta: Sinar Grafika, 2013)

Hanbal, Ahmad bin, Musnad Ahmad. CD. Rom al-Maktabah al-Syamilah. Ridwana Media. Bab Musnad Abi Hurairah, no. 9187. jilid 19

Koentjaningrat, Kebudayaan, Mentalitas, dan Pembangunan, (Jakarta: Gramedia, 1985)

Koto, Alaiddin, Ilmu Fikih Dan Usul Fikih, (Jakarta: Rajawali Press, 2006)

M.A. Mannan, Ekonomi Islam, Teori dan Praktek, (Jakarta: PT. Intermasa, 1992)

Madjit, Nurcholis, Islam Kemoderenan Dan Keindonesiaan, (Bandung: Mizan, 1992)

Shomad, Abd, Hukum Islam: Penormaan Prinsip Syariah Dalam Hukum Islam, (Jakarta: Kencana, 2010)

Syukur, Suparman, Studi Islam Transformatif, (Yogyakarta: Pustaka Belajar, 2015)

Toni, Agus, Ekonomi Islam Dan Peranannya Dalam Membentuk Masyarakat Madani Jurnal Istithmar Vol. 2 No. 2, 2018 